\title{
ARSEN (AS) SEBAGAI UNSUR PENUNJUK MINERALISASI EMAS TIPE EPITERMAL DI DAERAH CISOLOK KABUPATEN SUKABUMI JAWA BARAT
}

\author{
Oleh: \\ Kisman \\ Pusat Sumber Daya Geologi \\ Jl. Soekarno Hatta No. 444 Bandung
}

SARI

Mineralisasi emas yang terdapat di zona alterasi biasanya ditandai dengan adanya mineral sulfida sebagai mineral penunjuk. Unsur As dalam bentuk mineral arsenopyrite $\left(\mathrm{FeAsS}_{2}\right.$ ) adalah salah satu unsur yang memiliki hubungan dengan keberadaan emas di daerah penyelidikan. Korelasi antara unsur Au dan As memiliki angka positif 0,1375 hal ini berarti bahwa keduanya memiliki hubungan keterjadian sehingga arsen dapat dijadikan sebagai unsur penunjuk mineralisasi tipe epitermal karena pembentukan unsur arsen pada suhu rendah.

Alterasi yang terdapat pada lingkungan batuan vulkanik yang diterobos oleh batuan intrusi yang lebih muda akan menghasilkan mineralisasi endapan emas primer yang ideal.

Kata kunci : zona alterasi, mineral arsenopirit, mineralisasi emas, unsur arsen

\section{ABSTRACT}

Gold mineralization occured in the alteration zones are usually characterized by the presence of sulfide minerals as mineral guide. Arsenic (As) element in the mineral forms of arsenopyrite $\left(\mathrm{FeAsS} \mathrm{S}_{2}\right)$ is one of the element that have positive correlation with the gold in research area. The correlation of Au and As elements have positive number of 0.1375 that indicated the two element have genetic relations, so arsenic element can be used as pathfinder in epithermal mineralization type since the arsenic element formed at low temperature.

The alteration is contained in the environment of volcanic rocks, intruded by the younger intrusive rock to generate primary gold deposites mineralization ideally.

Keywords : alteration zone, arsenopyrite mineral, gold mineralization, arsenic element

\section{PENDAHULUAN}

Cebakan logam dasar dan logam mulia (emas) dibentuk oleh proses hidrotermal dan termasuk cebakan yang umum ditemukan di Indonesia. Keterdapatan cebakan atau mineralisasi sudah dikenal hampir diseluruh daratan wilayah Indonesia, karena sebagian besar merupakan jalur gunungapi terutama Pulau Jawa. Jalur gunungapi yang terdapat di Pulau Jawa yang dikenal dengan Jalur Pegunungan Selatan Jawa terbukti pada beberapa tempat memiliki kandungan mineral logam yang cukup menjanjikan secara ekonomis. Daerah penyelidikan Cisolok Kabupaten Sukabumi

termasuk di dalam jalur tersebut (Gambar 1).

Pembentukan gunungapi sangat erat hubungannya dengan magmatisma yang menerobos lapisan batuan hingga muncul di permukaan. Intrusi magma akan menyebabkan terjadinya ubahan dan mineralisasi pada batuan sekitarnya.

Tulisan ini dimaksudkan untuk mengetahui hubungan antara mineralisasi emas yang berasosiasi dengan arsen (As) sehingga dapat diketahui seberapa besar korelasinya dan apakah dapat dijadikan sebagai mineral penunjuk (pathfinder) pada penentuan mineralisasi tipe epitermal. 


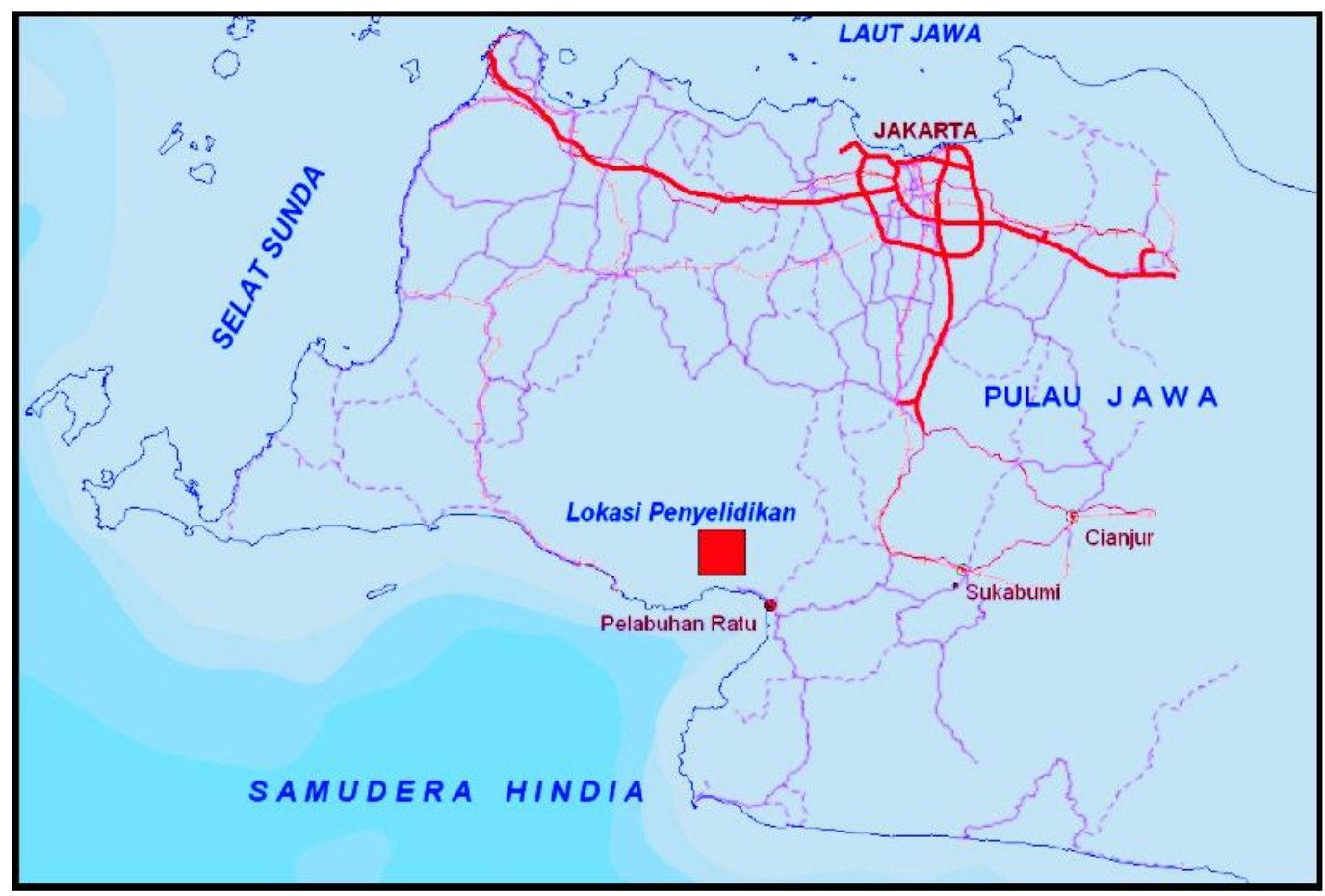

Gambar 1. Peta Lokasi Penyelidikan

\section{GEOLOGI UMUM DAN MINERALISASI}

Lajur pegunungan selatan Jawa Barat sangat dipengaruhi oleh proses tektonik regional Jawa Barat sebagai akibat Tangential stress dengan arah umum UUT SSB (Katilli dan Koesoemadinata, 1962 dalam Soeharto 1993, dalam Sahat 2002), akibat pergerakan aktif tektonik lempeng Samudera Hindia yang berada di bagian selatannya. Lempeng tersebut menyusup masuk ke benua Asia, menyebabkan munculnya aktivitas orogenesa dan vulkanisma, yang diikuti oleh proses ubahan hidrotermal dan mineraliasi secara berulang. Salah satu akibat adanya tektonik tadi telah menghasilkan sistim struktur geologi Kubah Bayah (Bayah Dome) dengan arah umum utara - selatan, diperkirakan mempunyai hubungan erat dengan penyebaran urat-urat kuarsa yang termineralisasi.

Daerah penyelidikan ditempati oleh batuan dengan susunan batuan tertua di daerah ini adalah Formasi Citirem terdiri dari aliran lava berkomposisi diabas, basalt, syenit dan spilit yang berumur Kapur (Sujatmiko dan S. Santosa, 1992 dalam Sahat 2002). Formasi Citirem ditutupi tidakselaras oleh Komplek Melange Ciletuh, terdiri dari batuan berkomposisi basa dan ultrabasa (gabbro, peridotit dan serpentinit), sekis, klorit, pirit dan berbagai batuan sedimen.

Formasi Ciletuh ditutupi tidakselaras oleh Formasi Jampang berumur Oligosen Miosen yang telah mengalami ubahan propilitisasi akibat diterobos batuan berkomposisi andesitik dan basaltik. Beberapa terobosan batuan beku dari berbagai umur tersebar di beberapa tempat diantaranya adalah :

- Batuan diorit porfir berumur Oligosen Atas

- Batuan porfir Cilegok dan dasit Ciemas, andesit hornblende berumur Miosen Bawah

- Batuan diorit kuarsa dan dasit berumur Miosen Tengah

- Batuan andesit hornblenda dan andesit piroksen berumur Pliosen.

Batuan tersebut diatas pada umumnya menerobos batuan-batuan gunung api yang menyebabkan terjadinya ubahan dan mineralisasi di beberapa tempat.

Batuan-batuan sedimen vulkanik yang disebut Formasi Old Andesit berumur Tersier (Sahat, 2002), di beberapa tempat telah mengalami ubahan hidrotermal dan mineralisasi akibat diterobos batuan yang lebih muda.

Sedangkan di daerah Jampang ditemukan urat-urat kuarsa yang kedudukannya hampir berarah utara-selatan 


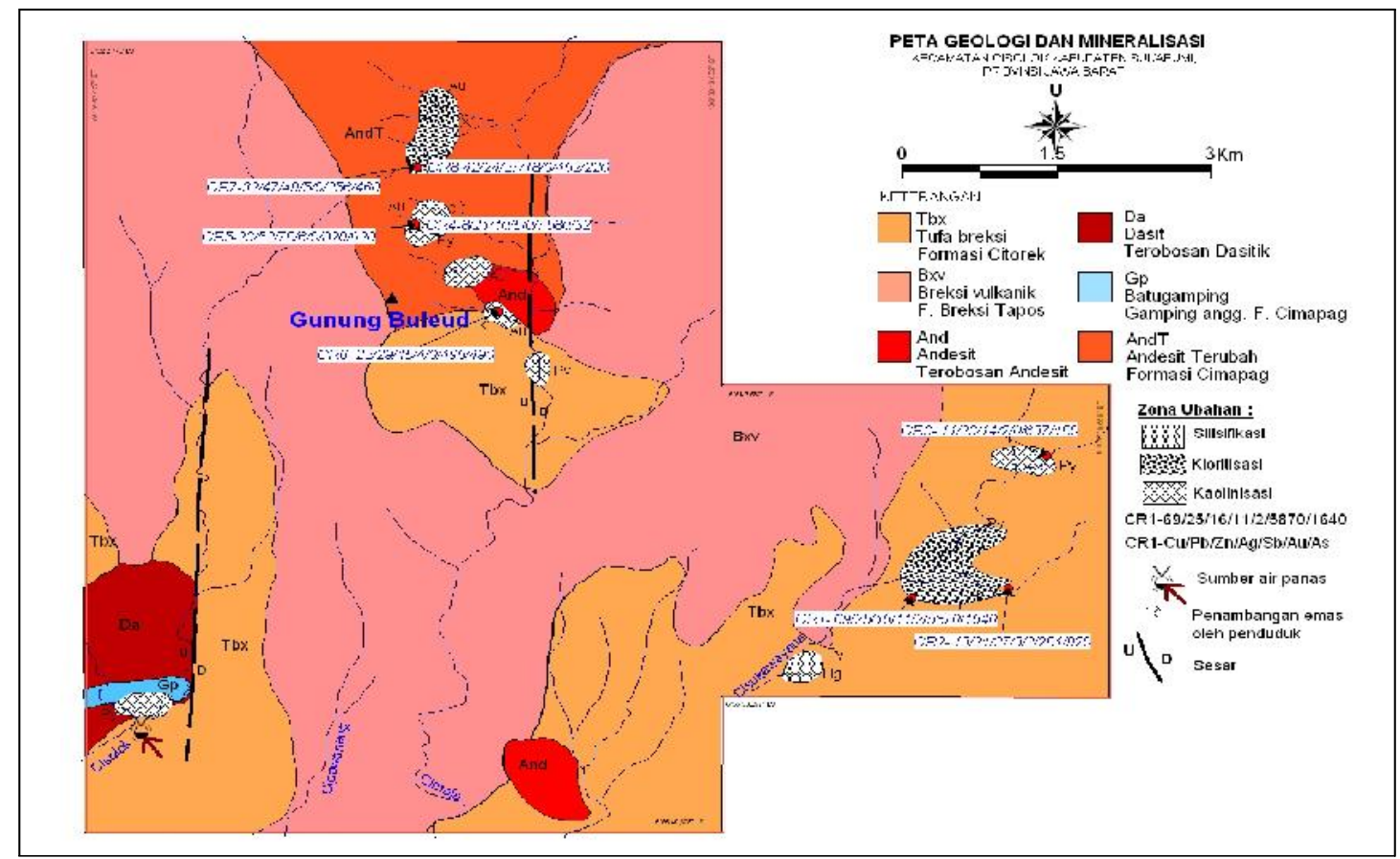

Gambar 2. Peta Geologi dan Mineralisasi Daerah Cisolok, Kabupaten Sukabumi Jawa Barat

biasanya sebagai pembawa mineralisasi (Soemarto B.,K., 1994).

Urat-urat kuarsa di dalam batuan terkersikkan dan argilic overprinting propylitic rock menunjukkan tekstur colloform serta terdapatnya asosiasi kuarsa-serisit-sulfida yang diduga sebagai tipe epitermal (Sahat, 2002).

\section{GEOLOGI DAN MINERALISASI DAERAH CISOLOK}

Morfologi pegunungan dicirikan oleh topografi yang umumnya membentuk punggungan berarah utara-selatan. Beberapa titik ketinggian yang termasuk kedalam satuan morfologi ini diantaranya adalah Gunung Buleud dan Gunung Gombong. Batuan-batuan yang membentuk morfologi ini adalah tufa breksi, breksi vulkanik, andesit terubah serta batuan terobosan andesit (Gambar 2).

Pada Gambar 2 disajikan pula hasil analisis kimia batuan yang dilengkapi dengan nomor conto dan titik lokasi pengambilannya, sehingga lebih jelas formasi batuannya sebagai induk mineralisasi yang terjadi. Penulisan hasil analisis kimia pada gambar tersebut berturut-turut menunjukkan nomor kode conto dan nilai kadar unsur $\mathrm{Cu}, \mathrm{Pb}, \mathrm{Zn}, \mathrm{Ag}$,
$\mathrm{Sb}, \mathrm{Au}$ dan As. Titik lokasi dengan tanda lingkaran kecil merah terdapat dua lokasi yang berimpit yaitu CR4 dengan CR5 dan CR7 dengan CR8. Conto-conto diambil semuanya dari batuan yang mengalami alterasi baik silisifikasi, kloritisasi dan kaolinisasi.

Batuan terobosan yang ditemukan di daerah ini yaitu batuan andesit dan batuan dasit. Batuan terobosan andesit ditemukan di bagian utara ( sekitar Gunung Buleud) dan di bagian selatan menerobos satuan batuan andesit dan tufa breksi. Secara megaskopis batuan ini memperlihatkan warna abu-abu kehijauan, tekstur porfiritik dengan fenokrist piroksen dan amfibol. Batuan ini diperkirakan sebagai pembawa mineralisasi logam di daerah ini. Batuan terobosan dasit ditemukan di bagian baratdaya daerah penyelidikan, secara fisik berwarna abuabu, tekstur porfiritik, membentuk perbukitan yang agak menonjol daripada daerah sekitarnya.

Berdasarkan pengamatan lapangan ada dua struktur sesar normal yang berkembang di daerah ini yaitu sesar normal Gunung Buleud dan sesar normal Nagrak. Kedua sesar ini berarah hampir utaraselatan. Beberapa indikasi terdapatnya sesar ini antara lain adalah berupa breksi sesar di Sungai Cikadu dan beberapa mata 
air panas salah satunya di Sungai Cisolok pada posisi sudut kiri bawah pada peta daerah penyelidikan.

Mineralisasi yang menarik di bagian timur dan tenggara daerah penyelidikan (sekitar Desa Cileungsing) adalah munculnya mineral-mineral yang biasanya terbentuk pada suhu rendah dan dangkal seperti stibnit dan sinabar. Kedua mineral ini dijumpai di Sungai Cipinang (CR2).

Ubahan silisifikasi dengan hadirnya kalsedon bersama dengan pirit dijumpai pada tufa breksi di Sungai Sukawayana dalam lubang bekas penggalian penduduk setempat (Gambar 4). Ke arah timur daerah penyelidikan (Sungai Cipinang dan Sungai
Cilarangan) pada umumnya merupakan zona alterasi kloritisasi dan kaolinisasi yang menyebar secara luas hingga ke arah tenggara, yang juga teramati di punggungan-punggungan.

\section{Hasil Analisis Laboratorium}

Hasil analisis kimia delapan conto batuan termineralisasi dari daerah Kecamatan Cisolok/Cikakak Sukabumi disajikan pada Tabel-1 dan korelasi antar unsur pada Tabel2, foto singkapan urat kuarsa dan sebagian hasil analisis petrografi dan mineragrafi dapat dilihat pada Gambar 3 sampai Gambar 8.

Tabel 1.

Hasil Analisis Kimia Conto Batuan Daerah Cisolok/Cikakak, Kabupaten Sukabumi (Sahat, 2002)

\begin{tabular}{|c|r|r|r|r|r|r|r|}
\hline $\begin{array}{c}\text { KODE } \\
\text { CONTO }\end{array}$ & $\begin{array}{c}\text { Cu } \\
(\mathrm{ppm})\end{array}$ & \multicolumn{1}{c|}{$\begin{array}{c}\mathrm{Pb} \\
(\mathrm{ppm})\end{array}$} & $\begin{array}{c}\mathrm{Zn} \\
(\mathrm{ppm})\end{array}$ & $\begin{array}{c}\mathrm{Ag} \\
(\mathrm{ppm})\end{array}$ & $\begin{array}{c}\text { Sb } \\
(\mathrm{ppm})\end{array}$ & $\begin{array}{c}\mathrm{Au} \\
(\mathrm{ppb})\end{array}$ & $\begin{array}{c}\text { As } \\
(\mathrm{ppm})\end{array}$ \\
\hline CR1 & 69 & 25 & 16 & 11 & 2 & 5870 & 1640 \\
\hline CR2 & 13 & 21 & 27 & 3 & 2 & 281 & 920 \\
\hline CR3 & 11 & 23 & 14 & 2 & 0 & 637 & 180 \\
\hline CR4 & 8 & 21 & 10 & 5 & 0 & 7580 & 32 \\
\hline CR5 & 23 & 52 & 78 & 6 & 0 & 820 & 920 \\
\hline CR6 & 22 & 29 & 45 & 4 & 0 & 496 & 490 \\
\hline CR7 & 32 & 47 & 49 & 5 & 0 & 256 & 460 \\
\hline CR8 & 42 & 24 & 27 & 18 & 0 & 462 & 220 \\
\hline
\end{tabular}

Tabel 2.

Korelasi antar unsur $\mathrm{Cu}, \mathrm{Pb}, \mathrm{Zn}, \mathrm{Ag}, \mathrm{Sb}, \mathrm{Au}$ dan $\mathrm{As}$ Conto Batuan

Daerah Cisolok/Cikakak, Kabupaten Sukabumi

\begin{tabular}{|c|r|r|c|c|c|c|c|}
\hline & \multicolumn{1}{c|}{$\mathrm{Cu}$} & $\mathrm{Pb}$ & $\mathrm{Zn}$ & $\mathrm{Ag}$ & $\mathrm{Sb}$ & $\mathrm{Au}$ & $\mathrm{As}$ \\
\hline $\mathrm{Cu}$ & 1,0000 & & & & & & \\
\hline $\mathrm{Pb}$ & 0,0635 & 1,0000 & & & & & \\
\hline $\mathrm{Zn}$ & $-0,0431$ & 0,9001 & 1,0000 & & & & \\
\hline $\mathrm{Ag}$ & 0,6907 & $-0,1095$ & $-0,0961$ & 1,0000 & & & \\
\hline $\mathrm{Sb}$ & 0,4118 & $-0,3662$ & $-0,3165$ & 0,0292 & 1,0000 & & \\
\hline $\mathrm{Au}$ & 0,1993 & $-0,3576$ & $-0,5279$ & 0,0958 & 0,2162 & 1,0000 & \\
\hline $\mathrm{As}$ & 0,6610 & 0,1547 & 0,1714 & 0,1145 & 0,7839 & 0,1375 & 1,0000 \\
\hline
\end{tabular}




\section{MAKALAH ILMIAH}

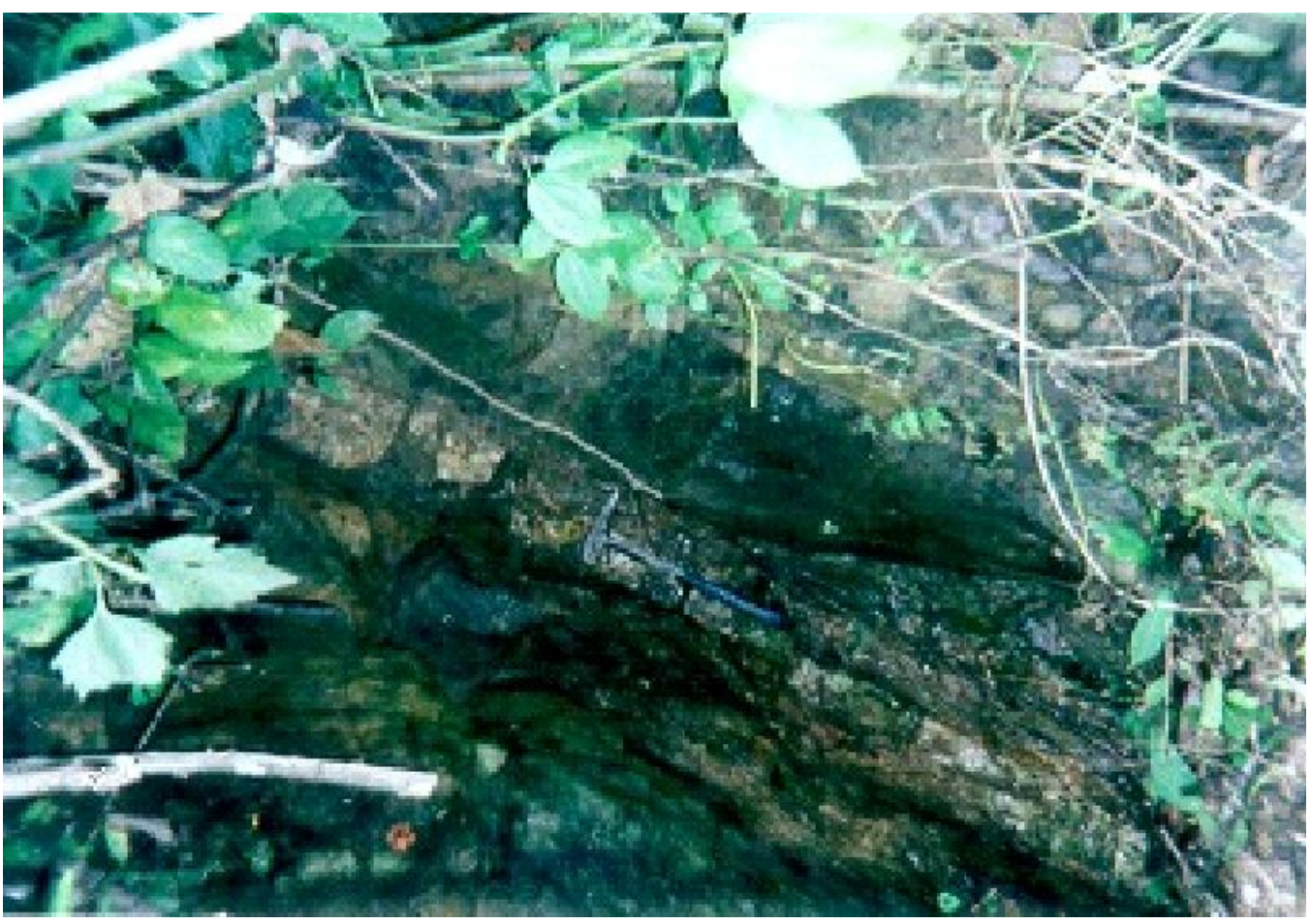

Gambar 3. Foto Urat kuarsa (CR7) $\mathrm{U} 10^{\circ} \mathrm{T} / 60^{\circ}$, lebar $10-15 \mathrm{~cm}$ dalam batuan andesit terubah, mengandung Au $256 \mathrm{ppb}$, As $460 \mathrm{ppm}$

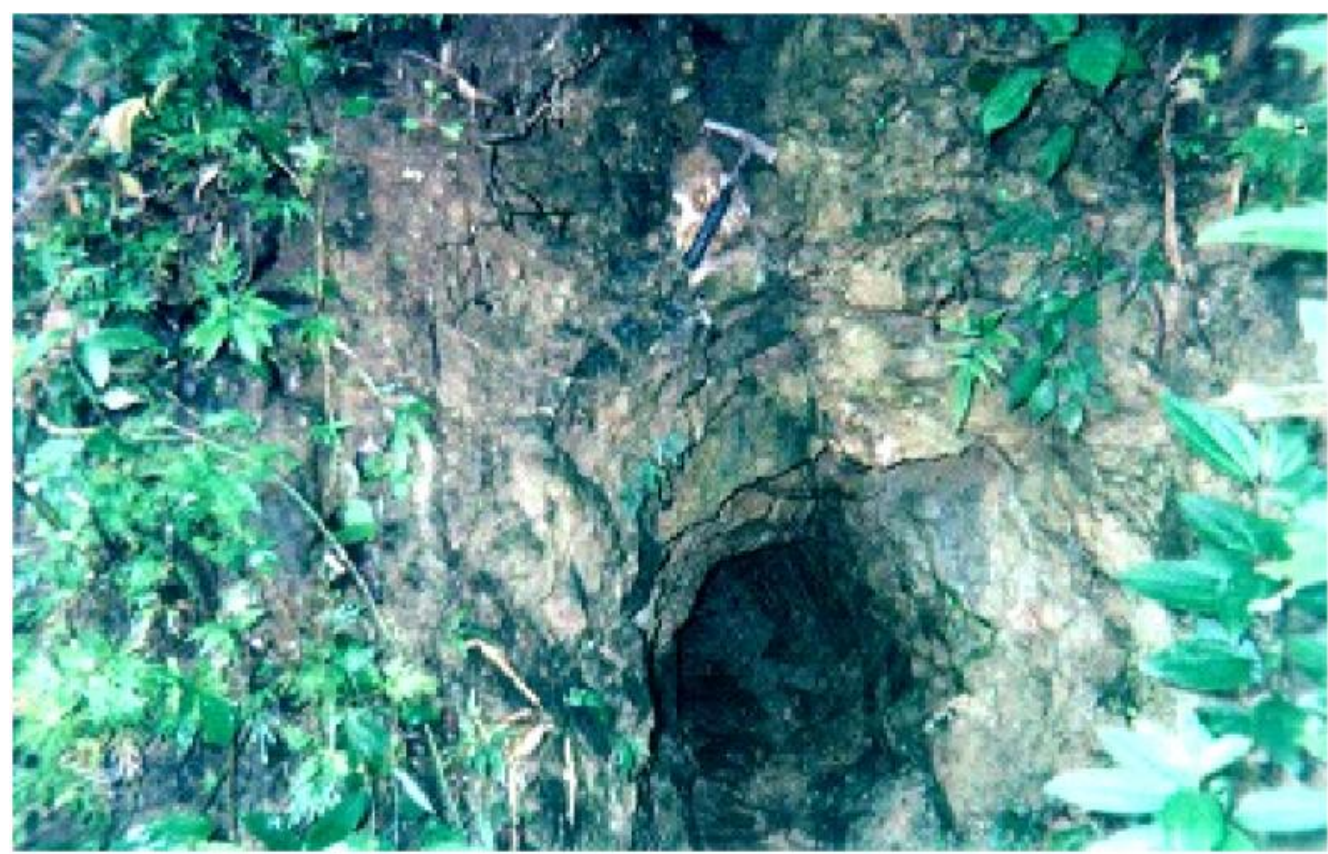

Gambar 4. Foto Lubang penambangan emas oleh penduduk disekitar Gunung Peti, Kecamatan Cisolok, urat kuarsa mengandung emas 


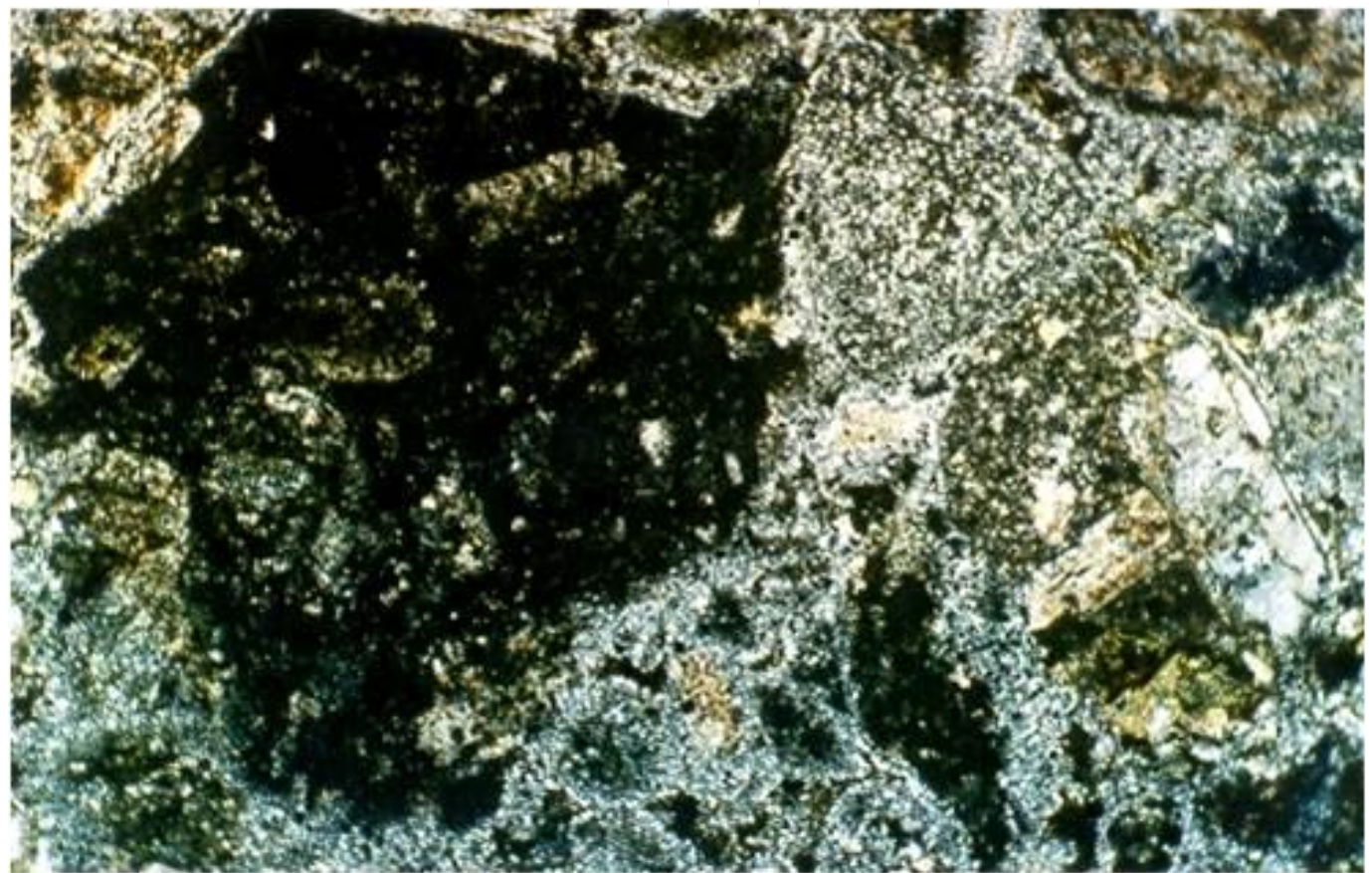

Gambar 5. Fotomikrograf sayatan tipis batuan tufa breksi (CR2). Tampak fragmen batuan telah mengalami ubahan-lempung-serisit dan kuarsa dengan pengisian kuarsa lempung sekunder sebagai semen (nikol bersilang $32 \mathrm{x}$ )

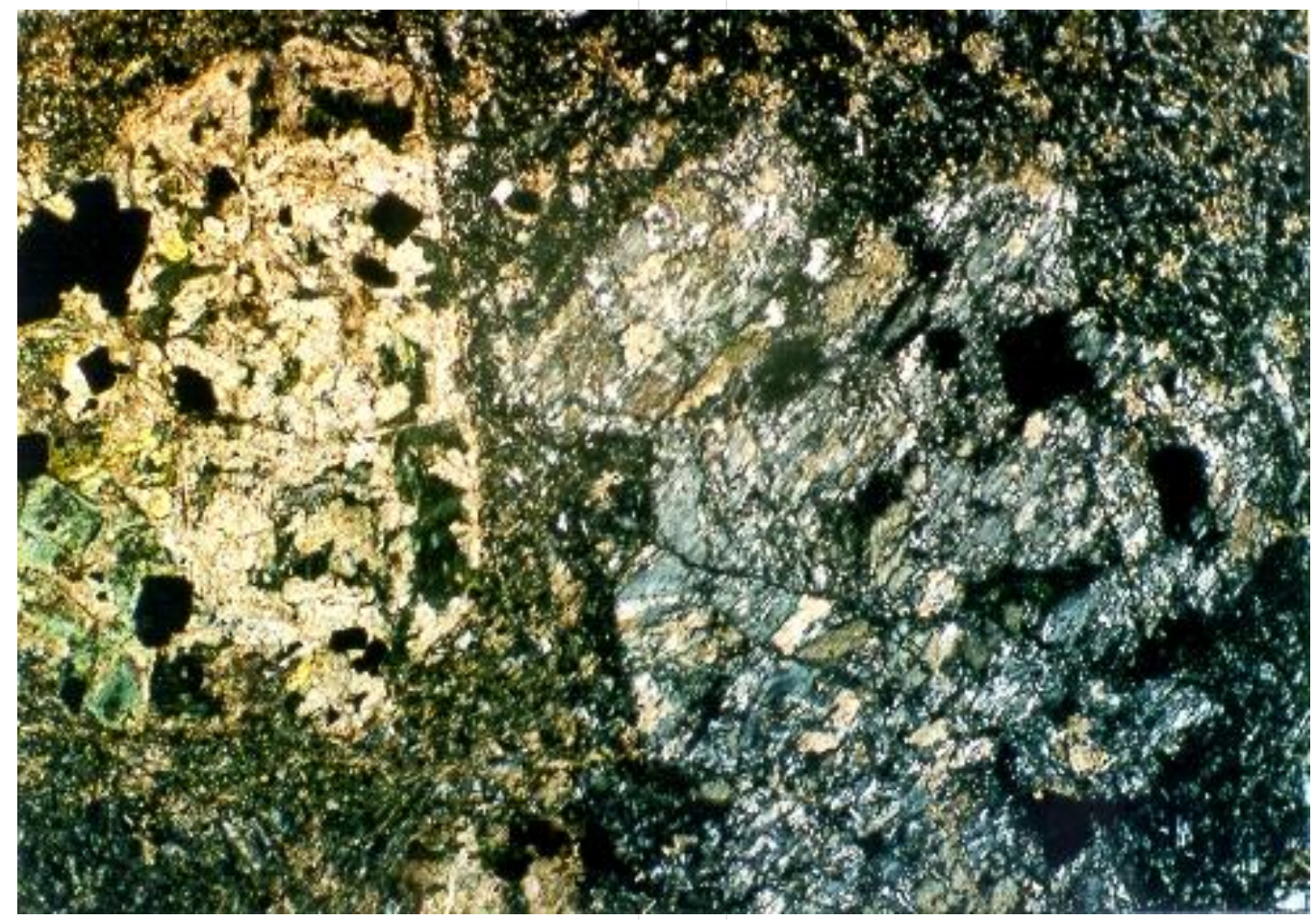

Gambar 6. Fotomikrograf sayatan tipis andesit terubah (CR4), tampak fenokrist plagioklas dan mineral mafik terubah menjadi karbonat-kalsit-mineral opak tertanam di dalam masadasar mikrolit plagioklas mafik dan opak (nikol bersilang $32 \mathrm{X})$. 


\section{MAKALAH ILMIAH}

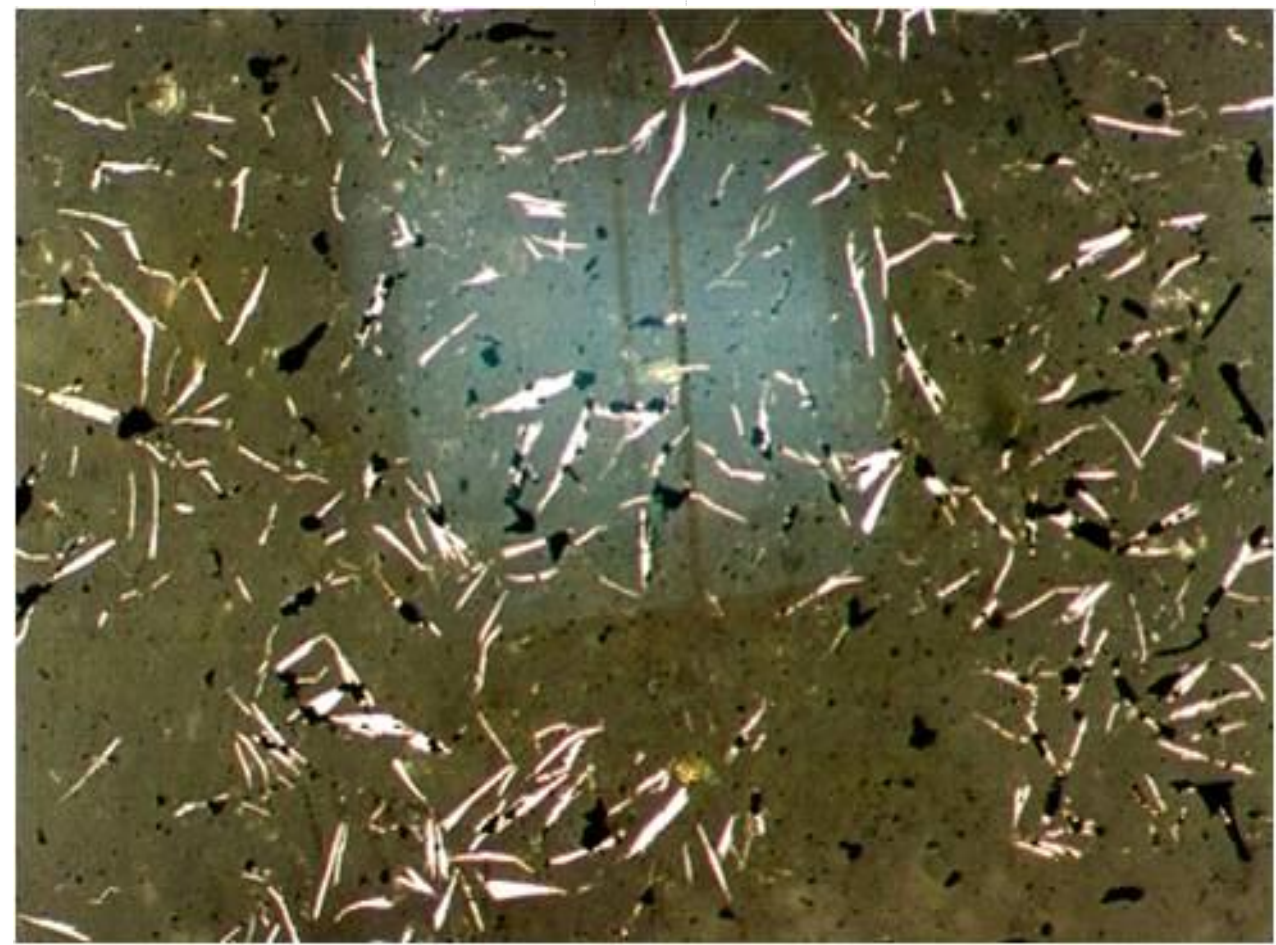

Gambar 7. Fotomikrograf sayatan poles (CR1) mengandung arsenopirit bentuk memanjang di dalam masadasar silikat (sinar pantul 40x)

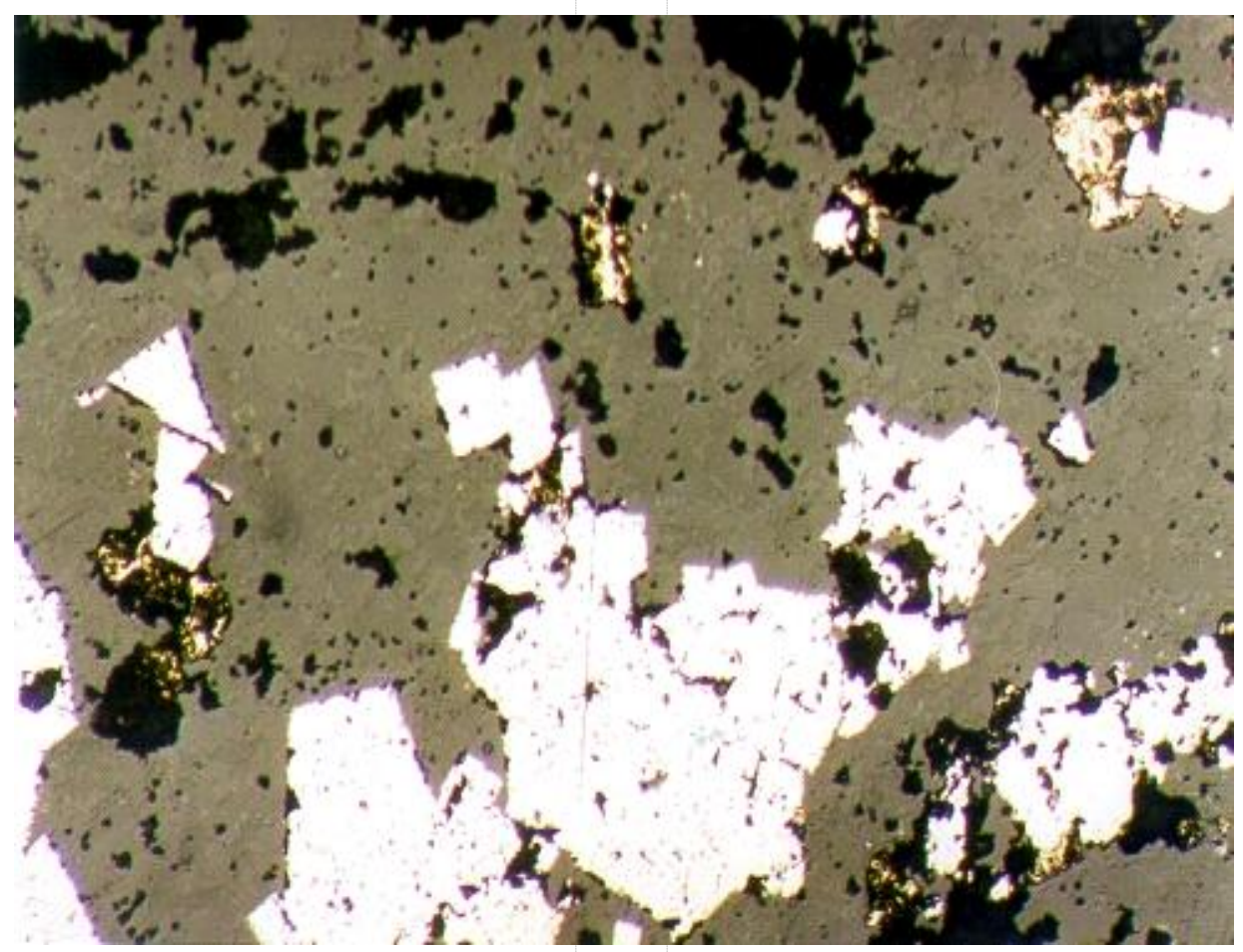

Gambar 8. Fotomikrograf sayatan poles (CR8), tampak pirit bersama arsenopirit dan kalkopirit (warna kuning) di dalam masa dasar silikat (sinar pantul $400 \mathrm{x}$ ) 


\section{PEMBAHASAN}

Banyak mineral-mineral yang mengandung As sangat besar, akan tetapi hanya beberapa mineral saja untuk keperluan praktis termasuk di dalamnya adalah mineral arsenopirit, lollingit, realgar, orpiment enargit, tennantit, luzonit (Maria Foldvari, 1978). Mineral arsenopirit (FeAsS ${ }_{2}$ ) menjadi penting dalam tulisan ini karena sebagian besar conto yang diambil dari daerah penyelidikan terdapat mineral tersebut terutama unsur As.

Hasil uji laboratorium delapan conto batuan terubah/termineralisasi yang dianalisis dari daerah Cisolok/Cikakak, menunjukkan kandungan kadar logam seperti pada Table 1. Pada tabel tersebut unsur logam $\mathrm{Cu}, \mathrm{Pb}, \mathrm{Zn}, \mathrm{Ag}$, dan $\mathrm{Sb}$ memperlihatkan kandungan yang sangat kecil < 100 ppm, sementara unsur Au menunjukkan nilai kandungan yang cukup berarti $(0,28 \mathrm{gr} / \mathrm{ton}-7,6 \mathrm{gr} / \mathrm{ton})$. Selain kadar Au yang tinggi juga kandungan As yang cukup signifikan dengan nilai 1.640 ppm.

Sehubungan dengan nilai kadar As yang cukup tinggi bersamaan dengan nilai $\mathrm{Au}$, maka secara tidak langsung dapat dikatakan keduanya memiliki hubungan kekerabatan dalam proses keterjadiannya. Pada sumber lain disebutkan bahwa pada dasarnya mineral bijih sulfida secara umum akan terdapat unsur traces dari As, Sb dan Bi (Hole M.,1981). Arsen dan antimon merupakan unsur pathfinder yang positif untuk mencari keterjadian emas (http://www.azomining.com/news.aspx?ne wsID=2506\&lang=id).

Nilai rata-rata kadar As dari delapan conto batuan 607,75 ppm adalah suatu angka yang menunjukkan jauh lebih tinggi jika dibandingkan dengan konsentrasi As rata-rata dari batuan vulkanik yang bersifat asam sebesar 3,5- 5,9 ppm atau pada batuan granitik sebesar 1,4 - 1,7 ppm (Onishi dan Sandell, 1956 dalam Maria Foldvari,1978). Nilai unsur $\mathrm{Cu}, \mathrm{Pb}, \mathrm{Zn}, \mathrm{Ag}$, $\mathrm{Sb}, \mathrm{Au}$ dan As jika dikorelasikan antar sesamanya sehingga dapat terlihat seperti pada Tabel 2, dengan

cara melihat susunan unsur pada baris di atas dan kolom unsur sebelah kiri, maka pertemuan angka sebelah kanan menunjukkan hubungan antar unsur tersebut. Sedangkan bila angka pertemuan dengan unsur yang sama nilainya satu. Nilainilai positif yang mendekati angka satu menunjukkan adanya hubungan keterjadian, sebaliknya nilai yang negatif tidak ada hubungan.

Nilai $\mathrm{Au}$ dengan unsur-unsur logam dasar, relatif rendah bahkan ada yang negatif. Kalau angkanya negatif berarti bahwa unsur Au tidak memiliki korelasi dengan unsur logam yang bersangkutan untuk dapat dijadikan sebagai pathfinder dalam melokalisir anomali emas. Sedangkan hubungan unsur Au dengan As menunjukkan angka positif 0,1375, hal ini berarti bahwa meskipun rendah namun masih memiliki kaitan yang dapat dijadikan sebagai pathfinder dalam melokalisir anomali emas. Begitupun unsur Au dengan $\mathrm{Sb}$ menunjukkan nilai positif 0,2161 , karena As dan $\mathrm{Sb}$ sebagaimana telah disebutkan di atas merupakan unsur-unsur pathfinder yang positif dalam mencari keterjadian emas.

Berkaitan dengan unsur penunjuk disebutkan pula bahwa pathfinder adalah indikasi yang jelas dengan nilai ambang 100 ppm As, 1 ppm Hg, and 50 ppm Sb (Ashton, L. W., 1989). Bijih epitermal banyak mengandung arsen, merkuri dan antimon seperti halnya emas dan perak (Nelson, Carl E., 1990). Dua pernyataan tersebut di atas dihubungkan dengan nilai yang dimiliki unsur As dari daerah penyelidikan, maka hal ini merupakan bukti bahwa arsen sebagai unsur penunjuk mineralisasi tipe epitermal di daerah Cisolok.

Selain itu juga dapat dilihat bukti fisik pada Gambar 3 dan Gambar 4 yang menunjukkan pengambilan conto batuan andesit yang terubah menjadi propilitik bahkan sampai ubahan kuat menjadi kaolinit di lokasi penggalian batuan oleh masyarakat di Gunung Peti.

Fotomikrograf sayatan tipis Gambar 5 dan Gambar 6 menunjukkan fragmen batuan telah mengalami ubahan-lempung-serisit dan andesit terubah dengan fenokris yang tertanam dalam masadasar mikrolit plagioklas. Ubahan seperti tersebut menghasilkan nilai unsur $A u$ cukup signifikan.

Pada Fotomikrograf sayatan poles Gambar 7 dan Gambar 8 yang mengandung mineral arsenopirit. Pada Gambar 7 terlihat 


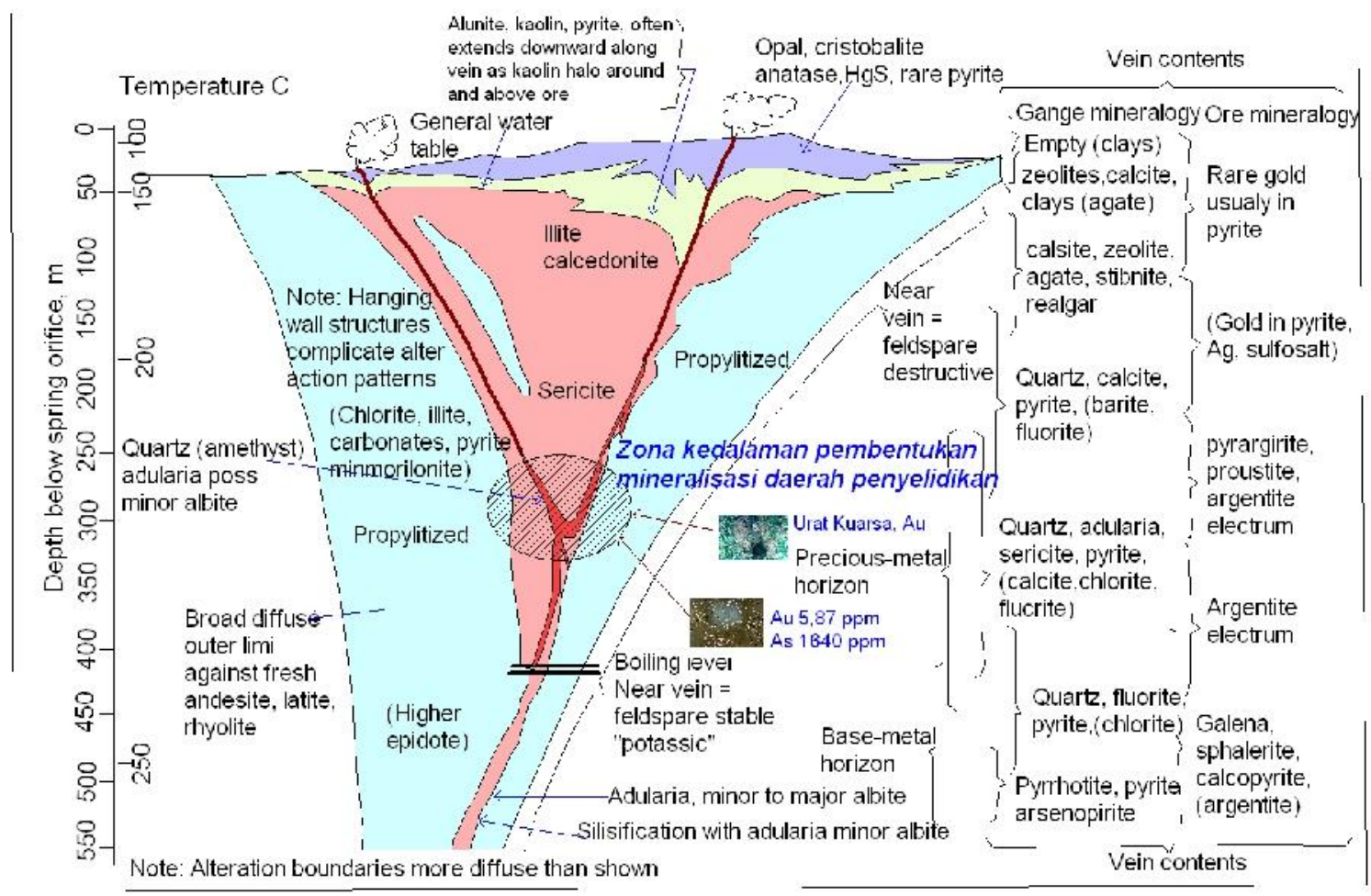

Gambar 9. Visualisasi model mineralisasi emas daerah Cisolok

(Modifikasi dari Buchanan,1980)

jelas mineral arsenopirit yang berbentuk memanjang di dalam masadasar silikat. Hampir seluruh permukaan dipenuhi oleh arsenopirit tanpa mineral lain, hal ini wajar dengan hasil analisis kimia yang cukup signifikan untuk kadar Au dan As paling tinggi diantara kedelapan conto batuan. Pada Gambar 8 terlihat mineral sulfida pirit bersama arsenopirit dan kalkopirit dalam masadasar silikat. Conto CR8 ini diambil pada zona ubahan kloritisasi di utara Gunung Buleud (lihat Gambar 2).

Berdasarkan karakteristik di atas diperkirakan kemungkinan pembentukan emas di daerah Cisolok/Cikakak adalah mineralisasi tipe epitermal dari jenis low sulfidation pada lingkungan batuan produk gunungapi. Kondisi mineralisasi di daerah Cisolok secara kasar ditafsirkan bahwa model atau tipe cebakan emas diuraikan dengan mengadopsi model Buchanan, 1980 seperti Gambar 9.

Adanya mineral-mineral stibnit dan sinabar di bagian selatan daerah penyelidikan dalam zona alterasi silisifikasi memberi petunjuk kemungkinan mineralisasi emas tipe epitermal, pada bagian penudung cap rock berada di sekitar daerah ini. Hanya cap rock yang dimaksud, saat ini sudah tidak ada karena terkikis akibat proses pelapukan dan erosi.

Keterdapatan urat-urat kuarsa diperkirakan bersamaan dengan pengendapan emas secara intensif di bagian utara daerah penyelidikan dan tidak ditemukan di bagian selatan/tenggara.

Keadaan ini diindikasikan bahwa bagian atas dari sistem epitermal berada di bagian selatan hingga tenggara dan bagian bawahnya ke arah utara. Gambar 9 menunjukkan bahwa pada awal terjadinya mineralisasi emas pada kedalaman sekitar $350 \mathrm{~m}$. Kontrol struktur pascamineralisasi teramati sepanjang zona breksiasi berarah utara-selatan di hulu Sungai Cimaja. Struktur ini menjadi pengontrol posisi urat-urat kuarsa dan di bagian barat dari bidang patahan sebagai hanging wall, sehingga merupakan daerah keterdapatan urat-urat kuarsa yang mengandung emas dan arsen secara intensif. 


\section{KESIMPULAN}

Mineral arsenopirit $\left(\mathrm{FeAsS}_{2}\right)$ di daerah penyelidikan Cisolok menjadi penting keberadaannya karena dapat membuktikan unsur As sebagai penunjuk keterdapatan cebakan emas primer di daerah tersebut. Pembuktian secara visual dengan conto yang sama pada mineragrafi dan analisis kimia dimana banyaknya kandungan arsenopirit juga kadar Au dan As lebih tinggi (conto CR1).

Korelasi unsur Au dengan As pada angka positif 0,1375 hal ini menunjukkan bahwa antara kedua unsur tersebut memiliki hubungan keterjadian. Nilai rata-rata kadar As dari delapan conto cukup signifikan sebesar 607,75 ppm, angka ini jauh lebih tinggi daripada angka yang disyaratkan oleh
Ashton, L. W., 1989 sebagai pathfinder dengan nilai ambang 100 ppm As.

Ditemukannya urat-urat kuarsa mengandung arsenopirit, emas, stibnit dan sinabar yang merupakan mineral-mineral hasil pembentukan pada suhu rendah adalah menunjukkan bahwa mineralisasi emas di daerah Cisolok merupakan tipe epitermal dari jenis low sulfidation pada lingkungan batuan produk gunungapi.

\section{Ucapan Terimakasih}

Penulis mengucapkan terima kasih kepada Kepala Pusat Sumber Daya Geologi, kepada Bapak Ir. Bambang Pardiarto, Ir. Teuku Islah dan Ir. Rahardjo Hutamadi yang telah memberikan koreksi dan masukan dalam perbaikan makalah ini.

\section{DAFTAR PUSTAKA}

Ashton, L. W., 1989, Geochemical exploration guidelines to disseminated gold deposits, AIME Transactions Volume 286

Foldvari Maria-Vogl, 1978, Theory and Practice of regional Geochemical Exploration, Akademiai Kiado, Budapest. p.22.

Hole M., 1981, Pathfinder applications of arsenic, antimony and bismuth in geochemical exploration, Applied Geochemistry Research Group, Imperial College, London England

Koesmono, M. dkk, 1996; Peta Geologi lembar Sindangbarang dan Bandarwaru, Jawa, skala 1: 100.000, Pusat Penelitian dan Pengembangan Geologi

Nelson, Carl E., 1990, Bulk Mineable Epithermal Precious Metal Deposits Of The Circum-Caribbean Region

Soemarto Bambang K.,1994, Studi Mineragrafi Bijih dan Batuan Ubahan Silikat di daerah Prospek Surade, Kabupaten Sukabumi, Puslitbang Geoteknologi LIPI.

Sahat S., dkk, 2002, Inventarisasi dan Evaluasi Mineral di Kabupaten Cianjur dan Kabupaten Sukabumi, Provinsi Jawa Barat, Direktorat Inventarisasi Sumberdaya Mineral.

Sutisna, D.T. dkk 1991; Eksplorasi Logam Mulia di daerah Jampang (Kabupaten Sukabumi- Cianjur) dan Bayah (Kabupaten Lebak), Jawa Barat, Kolokium 1991, Hasil Penyelidikan Sumberdaya Mineral Indonesia, Bandung 27 - 28 Nopember 1991, Direktorat Sumberdaya Mineral.

Sukamto, Rab. 1975; Peta Geologi Lembar Jampang dan Balekambang, Jawa, skala 1:100.000, Pusat Penelitian dan Pengembangan Geologi.

Sujatmiko dan Santosa.S, 1992 ; Peta Geologi Lembar Leuwidamar, Jawa, skala 1:100.000, Pusat Penelitian dan Pengembangan Geologi.

http://www.azomining.com/news.aspx?newsID=2506\&lang=id download

.aspx?news $\mid \mathrm{D}=2506$ \&lang=id download

Diterima tanggal 11 April 2011

Revisi tanggal 16 Mei 2011 